\title{
REACTION MECHANISM AND KINETICS OF SULFIDE COPPER CONCENTRATE OXIDATION AT ELEVATED TEMPERATURES
}

\author{
Aleksandra Mitovski $i^{*}$, Nada Štrbac ${ }^{1}$, Miroslav Sokic ${ }^{2}$, Milan Kragovic ${ }^{2}$, \\ Vesna Grekulović ${ }^{1}$ \\ ${ }^{1}$ University of Belgrade, Technical Faculty in Bor, \\ Vojske Jugoslavije 12, 19210 Bor, Serbia \\ ${ }^{2}$ Institute for Technology of Nuclear and Other Mineral Raw Materials, \\ Bulevar Franš D'Eperea, 11000 Belgrade, Serbia
}

Received 10.09.2017

Accepted 27.09.2017

\begin{abstract}
Sulfide copper concentrate from domestic ore deposit (Bor, Serbia) was subjected to oxidation in the air atmosphere due to a better understanding of reaction mechanism and oxidation of various sulfides present in the copper concentrate at elevated temperatures. Results of the initial sample characterization showed that concentrate is chalcopyrite-enargite-tennantite type, with an increased arsenic content. Characterization of the oxidation products showed the presence of sulfates, oxysulfates, and oxides. Based on predominance area diagrams for Me-S-O systems $(\mathrm{Me}=\mathrm{Cu}, \mathrm{Fe}$, As) combined with thermal analysis results, the reaction mechanism of the oxidation process was proposed. The reactions which occur in the temperature range $25-1000^{\circ} \mathrm{C}$ indicate that sulfides are unstable in the oxidative conditions. Sulfides from the initial sample decomposed into binary copper and iron sulfides and volatile arsenic oxides at lower temperatures. Further heating led to oxidation of sulfides into iron oxides and copper sulfates and oxysulfates. At higher temperatures sulfates and oxysulfates decomposed into oxides. Kinetic analysis of the oxidation process was done using Ozawa's method in the non-isothermal conditions. The values for activation energies showed that the reactions are chemically controlled and the temperature is the most influential parameter on the reaction rates.
\end{abstract}

Keywords: enargite; sulfides; characterization; roasting; heating rate.

* Corresponding author: Aleksandra Mitovski, amitovski@ttbor.bg.ac.rs 


\section{Introduction}

Copper ores in the world's exploiting deposits are being continually depleted, getting more complex, and grades of the valuable elements are constantly declining. These issues complicate pyrometallurgical processing and bring new requirements for management of the produced waste streams. Copper sulfides are often accompanied with many undesirable elements among which is arsenic. Arsenic hasn't got significant market value, but, as a toxic element, it has to be removed from ores, concentrates and other process streams because of the environmental or process reasons [1]. A wide range of arsenic-containing minerals exist in nature, and on many occasions; these minerals are associated with minerals of a commercial value. Sulfide copper ores are closely associated with minerals like enargite, $\mathrm{Cu}_{3} \mathrm{AsS}_{4}$ or tennantite $\mathrm{Cu}_{12} \mathrm{As}_{4} \mathrm{~S}_{13}$, which contain a significant amount of copper and precious metals. These arsenic sources can end up to wastewaters upon mineral processing, causing various environmental problems. Arsenic-containing effluents need to be treated before discharge or recycling [2].

Beneficiation of sulfide copper ores typically includes flotation. However, this process doesn't remove arsenic if it is present in the ores. After the beneficiation, copper concentrates are either subjected to roasting or to direct pyrometallurgical extraction (smelting and converting), depending on the copper amount in the concentrate. These stages are common to all conventional smelting processes and mainly involve the oxidation of the batch. When the oxygen is put into the system, the sulfide minerals will decompose, but given the iron has got a higher affinity for oxygen than copper at smelting temperatures, iron is preferentially oxidized [3]. In conventional flash smelting, heavy metal impurities end up either in the slag or eventually in blister copper $[4,5]$ from which they are eliminated by electrolytic refining. Copper slag, which contains heavy metals requires either a controlled disposal in a landfill [6] or a thorough clean-up before their safe disposal. Partial oxidation of copper concentrate containing sulfide minerals is carried out in order to reduce the sulfur content to the amount desirable for the smelting process and further, obtaining richer copper matte. The complexity of the reactions that occur during the oxidation of sulfide copper minerals is based on the fact that some of the phase transformations are simultaneous and their mutual influence during the roasting process in the air atmosphere should not be omitted.

The behavior of chalcopyrite based ores and concentrates during oxidative roasting at high temperatures was investigated from thermodynamic, thermal and kinetic aspects by several authors [7-11]. Thermal analysis techniques (differential thermal analysis, thermogravimetry) are proved as important tools to determine the concentrates' behavior during decomposition of copper iron sulfides and sulfur volatilization rates [12-15].

Oxidation of enargite at roasting temperatures and determining the reaction mechanism and kinetics [16], showed that reaction mechanism of enargite oxidation run in three sequential stages. Sulphation roasting studies on synthetic copper-iron sulfides with steam and oxygen [17] showed that copper sulfide formed copper sulfate with this gaseous mixture at $500{ }^{\circ} \mathrm{C}$. The kinetics study of the CuS-FeS system showed that activation energy value for this conversion was found to be $30.36 \mathrm{~kJ} \cdot \mathrm{mol}^{-1}$ in the temperature range 400 to $500{ }^{\circ} \mathrm{C}$. Thermal decomposition of three synthetic copper sulfides (chalcocite $\left(\mathrm{Cu}_{2} \mathrm{~S}\right)$, chalcopyrite $\left(\mathrm{CuFeS}_{2}\right)$, and enargite $\left(\mathrm{Cu}_{3} \mathrm{AsS}_{4}\right)$ ) and two 
commercial copper concentrates, studied on thermobalance and imaging furnace [18], demonstrated that the absence of oxygen, in combination with high decomposition temperatures furthers the removal of heavy metal impurities by volatilization.

Overall, there have been comparatively few published articles on the oxidation behavior and solution treatment processes for low-grade copper ores and complex concentrates because of their relatively low commercial importance in comparison to other, more dominant copper ores. A general observation is that these minerals are not amenable to many conventional processing routes [19]. A complete understanding of the oxidation behavior of sulfide particles at elevated temperatures is still objected of the investigation because the reaction mechanism of individual particles strongly depends upon a number of parameters (particle size, heating rate, the partial pressure of oxygen, amount of the impurities present in the particles, etc.) [20].

As a contribution to a better knowledge of the $\mathrm{Cu}-\mathrm{Me}-\mathrm{S}-\mathrm{O}$ system $(\mathrm{Me}=\mathrm{Fe}, \mathrm{As})$ and its behavior during oxidation at elevated temperatures, the results of thermal decomposition of sulfide copper concentrate samples from domestic ore deposit (Bor, Serbia) are presented in this paper. Kinetic analysis was done in non-isothermal conditions to obtain activation energies of the oxidation and to determine the most influential parameters on thermal decomposition.

\section{Experimental}

The samples for the experimental investigation were taken from homogenized and grained copper concentrate, obtained from domestic ore body " $\mathrm{H}$ " (vicinity of Bor, Republic of Serbia). Ore body "H" belongs to South-eastern group of Bor copper deposits, situated in Timok volcanogenic complex (Serbia) [21]. Chemical analysis of the initial sample was done on ICP-AES spectrometer "SPECTRO Ciros Vision". Characterization of the mineral forms present in the initial sample and oxidation products heated for one hour at 450, 650 and $900{ }^{\circ} \mathrm{C}$ was done by XRD analysis ("Philips" PW-1710). SEM/EDS analysis was done for the initial concentrate sample coated with gold on „Jeol“" model JSM-6610LV and on Oxford Instruments detector "X-Act". Thermal analysis (DTA/TG) was done on NETZSCH STA 409 EP with following experimental parameters: a mass of the sample $100 \mathrm{mg}$, heating rate $10{ }^{\circ} \mathrm{C}$ $\min ^{-1}$, temperature range $25-1000{ }^{\circ} \mathrm{C}$, in the air atmosphere. Predominance area diagrams for Me-S-O systems $(\mathrm{Me}=\mathrm{Cu}, \mathrm{Fe}, \mathrm{As})$ at $25^{\circ} \mathrm{C}, 450{ }^{\circ} \mathrm{C}, 650{ }^{\circ} \mathrm{C}$ and $900{ }^{\circ} \mathrm{C}$ were obtained using HSC Chemistry 6.1 database. Kinetic analysis of the concentrate oxidation was done using Ozawa's method of non-isothermal kinetics under heating rates $5,10,15$, and $20^{\circ} \mathrm{C} \mathrm{min}^{-1}$ within the heating range $25-1000{ }^{\circ} \mathrm{C}$. 


\section{Results and discussion}

Chemical analysis

Results of chemical analysis, shown in Table 1, indicate that the investigated concentrate is a low-grade sulfide copper concentrate with copper content below 10 mass $\%$. Iron and sulfur are present in similar amounts, and content of other detected elements is below 1 mass $\%$. The concentrate is overburdened with gangue minerals $\left(\mathrm{SiO}_{2}+\mathrm{Al}_{2} \mathrm{O}_{3}\right)$ which is almost $50 \%$ of total sample mass. Arsenic content is highly increased (3.44 mass \%), which is almost seven times higher than the upper limit of 0.5 mass \% for pyrometallurgical production of copper from sulfide ores and concentrates. Due to environmental risks, this concentrate must be pretreated in order to reduce the amount of arsenic, before entering the pyrometallurgical copper production.

Table 1. The chemical composition of the initial sample (mass \%).

\begin{tabular}{lllllllllllll}
\hline Element & $\mathrm{Cu}$ & $\mathrm{S}$ & $\mathrm{Fe}$ & $\mathrm{Zn}$ & $\mathrm{Sb}$ & $\mathrm{Pb}$ & $\mathrm{As}$ & $\mathrm{Ni}$ & $\mathrm{Cd}$ & $\mathrm{SiO}_{2}$ & $\mathrm{Al}_{2} \mathrm{O}_{3}$ & Other
\end{tabular}

\begin{tabular}{llllllllllllll}
\hline Content & 9.52 & 11.0 & 10.07 & 0.18 & 0.15 & 0.006 & 3.44 & 0.0005 & 0.0009 & 49.34 & 0.014 & 8.62
\end{tabular}

$X$-ray structural analysis

XRD powder diffraction patterns of the initial concentrate sample and oxidation products are comparatively given in Fig. 1. Characterization of minerals present in the initial sample showed that concentrate consisted of binary copper-iron sulfide chalcopyrite $\left(\mathrm{CuFeS}_{2}\right)$, as well as copper-arsenic sulfides, enargite $\left(\mathrm{Cu}_{3} \mathrm{AsS}_{4}\right)$ and tennantite $\left(\mathrm{Cu}_{12} \mathrm{As}_{4} \mathrm{~S}_{13}\right)$. The residue consists of gangue minerals olivine and quartz. In the structure of oxidation products at $450{ }^{\circ} \mathrm{C}$, chalcocyanite $\left(\mathrm{CuSO}_{4}\right)$ was detected, while iron from the chalcopyrite oxidized into hematite $\left(\mathrm{Fe}_{2} \mathrm{O}_{3}\right)$, which was also observed in the oxidation products at $650{ }^{\circ} \mathrm{C}$ and $900{ }^{\circ} \mathrm{C}$. The structure of the products after heating at $650{ }^{\circ} \mathrm{C}$ consisted of dolerophanite $\left(\mathrm{CuO} \cdot \mathrm{CuSO}_{4}\right)$. At $900{ }^{\circ} \mathrm{C}$ tenorite $(\mathrm{CuO})$ and cuprite $\left(\mathrm{Cu}_{2} \mathrm{O}\right)$ were found, besides hematite $\left(\mathrm{Fe}_{2} \mathrm{O}_{3}\right)$, magnetite $\left(\mathrm{Fe}_{3} \mathrm{O}_{4}\right)$ and metastable spinel maghemite $\left(\gamma \mathrm{Fe}_{2} \mathrm{O}_{3}\right)$. The XRD analysis results showed that arsenic present in the initial sample as enargite and tennantite volatilized fully since it was not detected in the oxidation products at higher temperatures. 


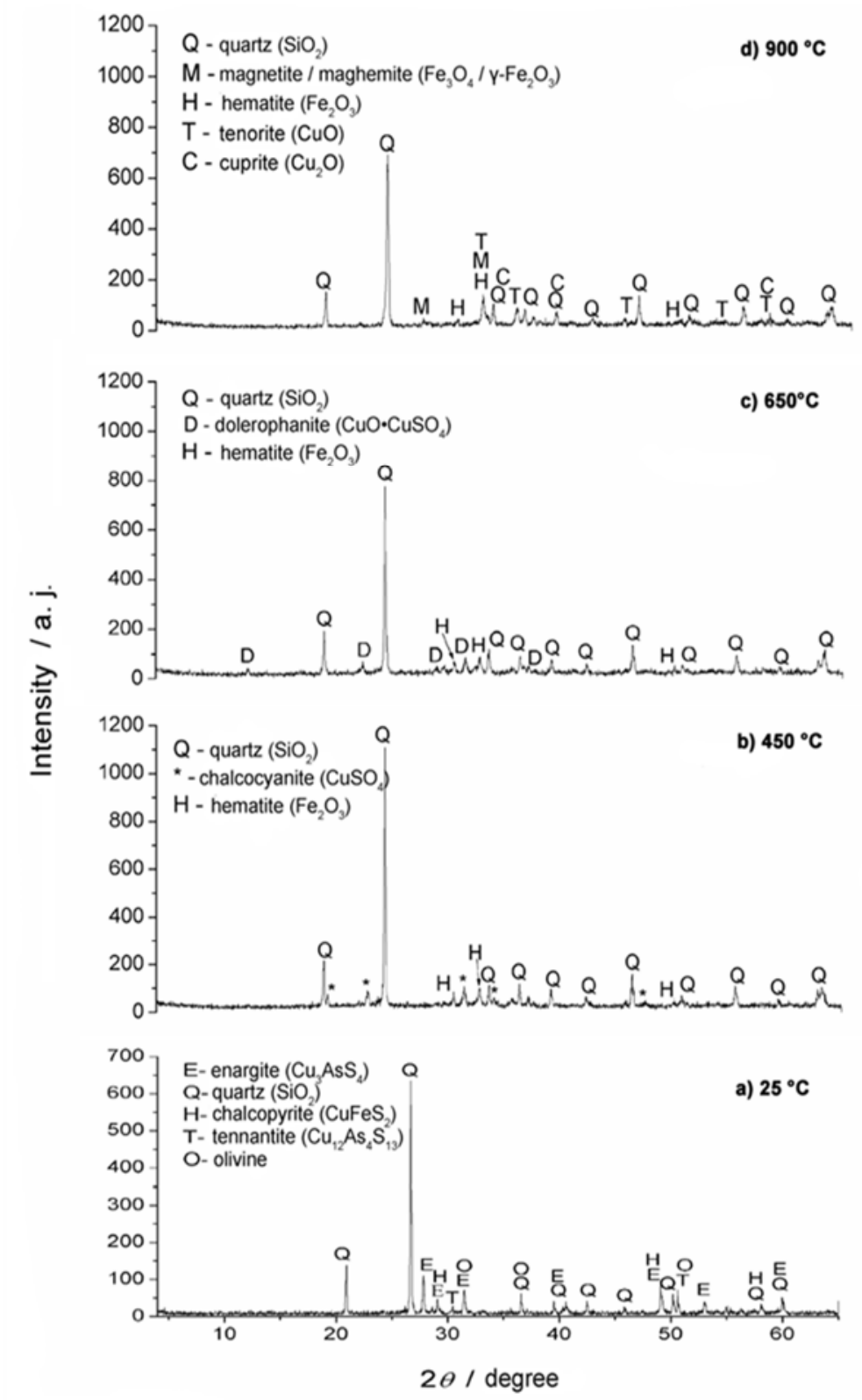

Fig. 1. Diffractograms of the initial sample (a) and oxidation products at $450{ }^{\circ} \mathrm{C}(b)$, $650{ }^{\circ} \mathrm{C}(c)$ and $900^{\circ} \mathrm{C}(d)$. 
Morphology of the initial sample, shown in Fig. 2 and Table 2, confirmed the presence of enargite $\left(\mathrm{Cu}_{3} \mathrm{AsS}_{4}\right)$ and tennantite $\left(\mathrm{Cu}_{12} \mathrm{As} 4 \mathrm{~S}_{13}\right)$. Quartz $\left(\mathrm{SiO}_{2}\right)$ was observed in all tested points. Iron was detected in the spectrum 1, probably as a component of olivine, because no sulfur was observed in the analyzed spectrum. The initial sample in all tested points showed the presence of arsenic.

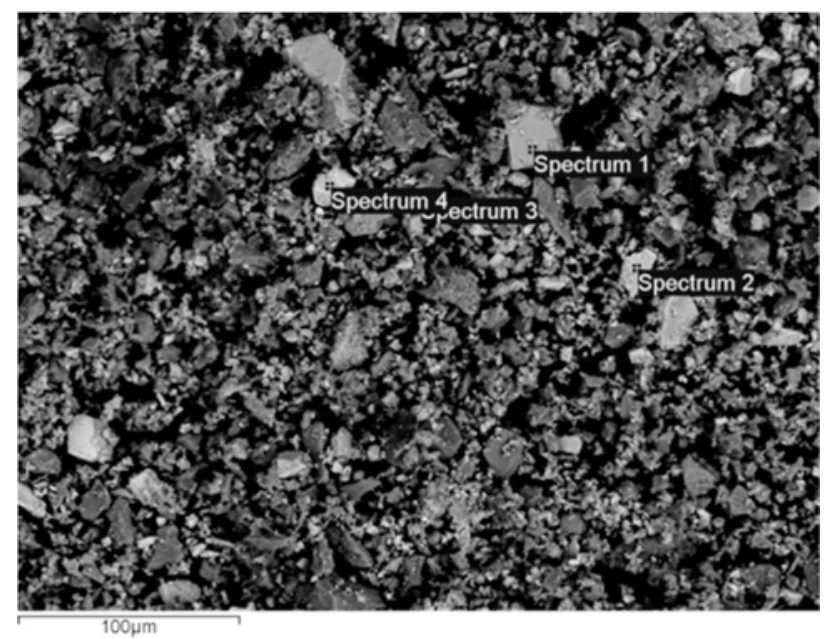

Fig. 2. Morphology of the initial concentrate sample.

Table 2. EDS analysis of the initial sample.

\begin{tabular}{lllll}
\hline Spectrum No. & 1 & 2 & 3 & 4 \\
\hline Element & \multicolumn{4}{c}{ mass \% } \\
\hline $\mathrm{Cu}$ & 1.7 & 35.0 & 4.3 & 46.8 \\
$\mathrm{Fe}$ & 45.8 & 0.0 & 0.0 & 0.0 \\
$\mathrm{~S}$ & 0.0 & 34.6 & 0.0 & 28.7 \\
$\mathrm{O}$ & 46.6 & 11.1 & 44.7 & 6.7 \\
$\mathrm{Si}$ & 4.3 & 0.9 & 49.3 & 1.9 \\
$\mathrm{As}$ & 1.6 & 18.3 & 1.7 & 15.9 \\
\hline
\end{tabular}

Thermal and thermodynamic analysis

Thermal and thermogravimetric tests were performed in order to define the reaction mechanism of the oxidation process. DTA and TG curves of the investigated sample are presented in Fig. 3. By heating in the air atmosphere, in the interval $25-310$ ${ }^{\circ} \mathrm{C}$ mass decrease in the sample was observed due to moisture removal, followed by an endothermic peak on DTA curve. Further heating in the range $310-600{ }^{\circ} \mathrm{C}$ indicated the occurrence of three successive exothermal peaks on DTA curve, with a significant mass decrease on TG curve in the interval $310-405^{\circ} \mathrm{C}$, which is in a good agreement with the literature [22-24]. Related peaks indicate there were three ongoing processes during oxidation. Studies by other authors in determining the mechanism of oxidation of realgar and auripigment mixtures, pointed to the existence of two sets of two connected exothermic peaks at $276{ }^{\circ} \mathrm{C}, 305{ }^{\circ} \mathrm{C}, 584{ }^{\circ} \mathrm{C}$ and $645{ }^{\circ} \mathrm{C}$, which was interpreted as the evaporation of arsenic oxides at lower temperatures and pyrite oxidation at elevated temperatures [25]. 


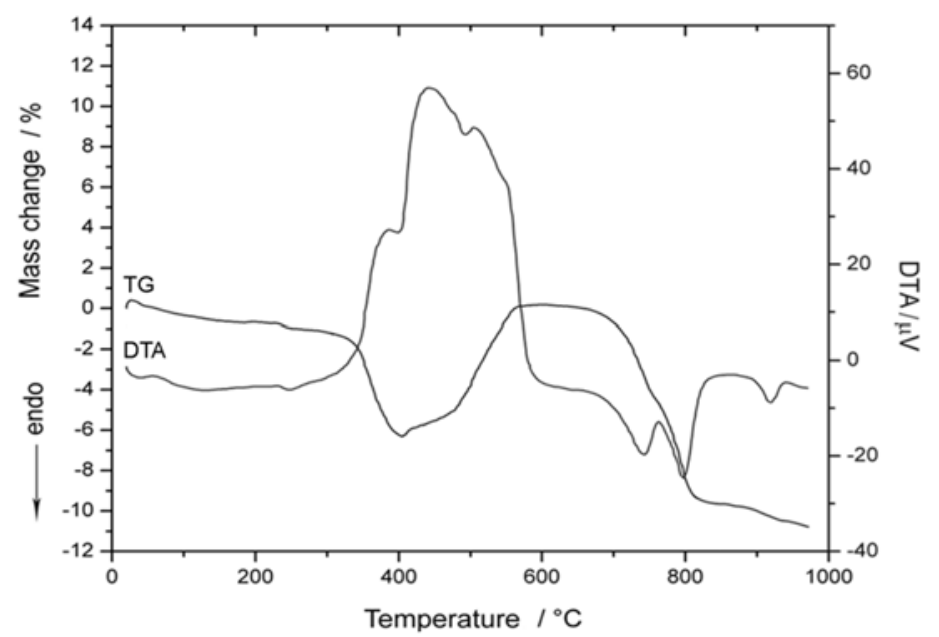

Fig. 3. DTA and TG curves of the sulfide copper concentrate sample.

As a useful tool for helping to determine the reaction mechanism of the oxidation process, predominance area diagrams (Kellog diagrams), for Me-S-O system $(\mathrm{Me}=\mathrm{Cu}$, $\mathrm{Fe}, \mathrm{As})$ at $25,450,650$ and $900{ }^{\circ} \mathrm{C}$ were plotted (Fig. 4), as functions log $\mathrm{p}_{\mathrm{SO} 2}(\mathrm{~g})=\mathrm{f}$ $\left(\log \mathrm{p}_{\mathrm{O} 2}(\mathrm{~g})\right)$, based on available thermodynamic data [26-28]. From predominance area diagrams optimum temperature and pressure conditions for the roasting of metal sulfides can be easily obtained [29].

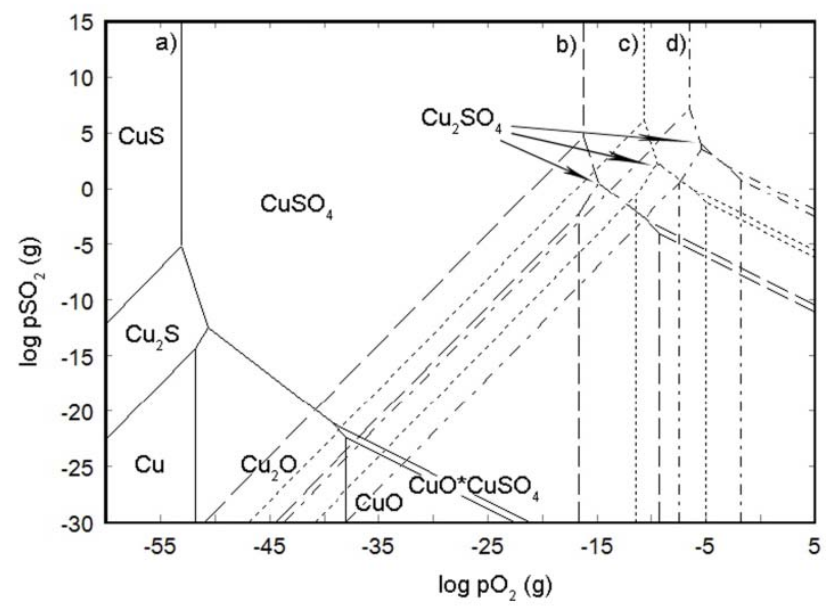

1) $\mathrm{Cu}-\mathrm{S}-\mathrm{O}$ 


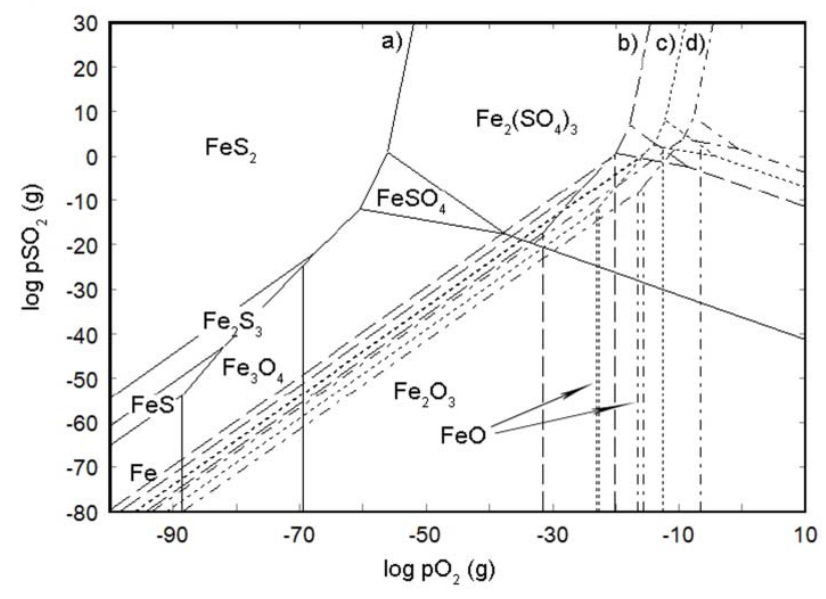

2) $\mathrm{Fe}-\mathrm{S}-\mathrm{O}$

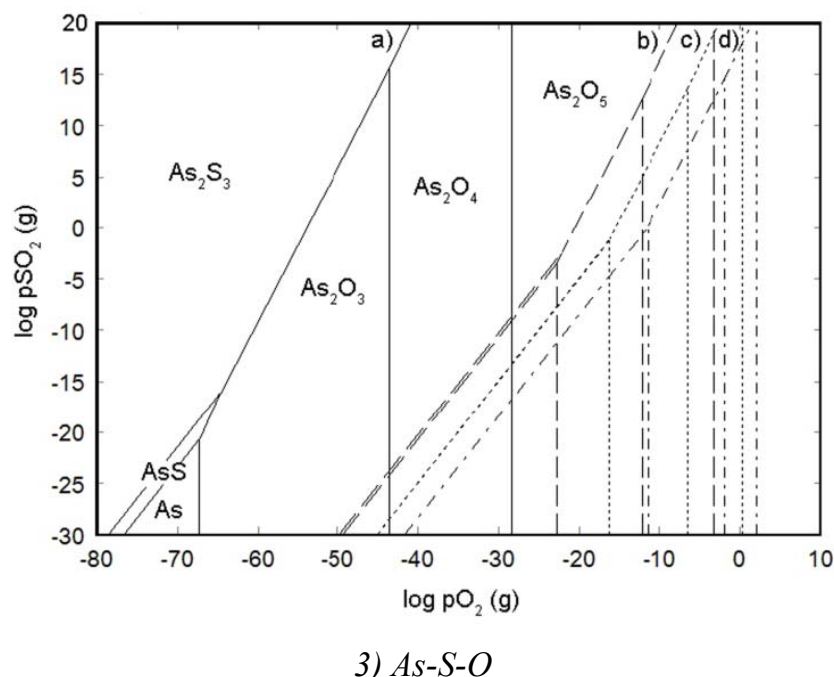

Fig. 4. Predominance area diagrams for the Me-S-O system $(\mathrm{Me}=\mathrm{Cu}, \mathrm{Fe}, \mathrm{As})$ at $25^{\circ} \mathrm{C}(\mathrm{a}), 450^{\circ} \mathrm{C}(\mathrm{b}), 650^{\circ} \mathrm{C}(\mathrm{c})$ and $900^{\circ} \mathrm{C}(\mathrm{d})$.

Predominance diagram for $\mathrm{Cu}-\mathrm{S}-\mathrm{O}$ system shows that oxidation of $\mathrm{CuS}$ in the air leads to the formation of copper sulfates and oxysulphates. The direct transformation from sulfide to oxide is not possible because there is no common line between $\mathrm{CuS}$ and $\mathrm{CuO}$ phase areas. The diagram for $\mathrm{Fe}-\mathrm{S}-\mathrm{O}$ system shows that iron sulfate is a stable phase at temperatures up to $450{ }^{\circ} \mathrm{C}$ and the reaction mechanism at this temperature follows oxidation of $\mathrm{FeS}_{2}$ over iron oxide, to lower and higher sulfate. At $650{ }^{\circ} \mathrm{C}$ and $900{ }^{\circ} \mathrm{C}, \mathrm{Fe}_{2} \mathrm{O}_{3}$ is the most thermodynamically stable phase, followed by transformation of higher to lower sulfides, which are further transformed to final oxide $\mathrm{Fe}_{2} \mathrm{O}_{3}$. As-S-O system shows different behavior during the oxidation compared to $\mathrm{Cu}-\mathrm{S}-\mathrm{O}$ and $\mathrm{Fe}-\mathrm{S}-\mathrm{O}$ 
systems, since arsenic does not form oxysulphates. $\mathrm{As}_{2} \mathrm{~S}_{3}$ oxidation in the air atmosphere at all investigated temperatures leads to volatile arsenic oxides formation.

According to the results obtained by XRD analysis, thermal analysis and data from predominance diagrams, following reaction mechanism of the sulfide copper concentrate oxidation in the temperature range $25-1000{ }^{\circ} \mathrm{C}$ can be defined.

The first exothermal peak on DTA curve at $385{ }^{\circ} \mathrm{C}$ relates to chalcopyrite oxidation [22]:

$$
2 \mathrm{CuFeS}_{2}+\mathrm{O}_{2}(\mathrm{~g}) \rightarrow \mathrm{Cu}_{2} \mathrm{~S}+2 \mathrm{FeS}+\mathrm{SO}_{2}(\mathrm{~g})
$$

The second exothermal peak at $442{ }^{\circ} \mathrm{C}$ represents a thermal change due to oxidation of enargite and tennantite, according to the following reactions [16]:

$$
\begin{aligned}
& 4 \mathrm{Cu}_{3} \mathrm{AsS}_{4}+13 \mathrm{O}_{2}(\mathrm{~g}) \rightarrow 6 \mathrm{Cu}_{2} \mathrm{~S}+\mathrm{As}_{4} \mathrm{O}_{6}(\mathrm{~g})+10 \mathrm{SO}_{2}(\mathrm{~g}) \\
& \mathrm{Cu}_{12} \mathrm{As}_{4} \mathrm{~S}_{13}+10 \mathrm{O}_{2}(\mathrm{~g})=6 \mathrm{Cu}_{2} \mathrm{~S}+\mathrm{As}_{4} \mathrm{O}_{6}(\mathrm{~g})+7 \mathrm{SO}_{2}(\mathrm{~g})
\end{aligned}
$$

Above $405^{\circ} \mathrm{C}$ mass increase can be observed on TG curve, which corresponds to oxidation of $\mathrm{FeS}$ (Eq. 4),

$$
2 \mathrm{FeS}+3,5 \mathrm{O}_{2}(\mathrm{~g}) \rightarrow \mathrm{Fe}_{2} \mathrm{O}_{3}+2 \mathrm{SO}_{2}(\mathrm{~g})
$$

while $\mathrm{Cu}_{2} \mathrm{~S}$, as the oxidation product from Eqs. 1-3 further oxidized forming chalcocyanite:

$$
\mathrm{Cu}_{2} \mathrm{~S}+\mathrm{O}_{2}(\mathrm{~g})+\mathrm{SO}_{2}(\mathrm{~g}) \rightarrow 2 \mathrm{CuSO}_{4}
$$

The third exothermal peak at $506{ }^{\circ} \mathrm{C}$, with the further mass increase, can be related to forming dolerophanite from chalcocyanite:

$$
4 \mathrm{CuSO}_{4}+2 \mathrm{SO}_{2}(\mathrm{~g})+\mathrm{O}_{2}(\mathrm{~g}) \rightarrow 2 \mathrm{CuO} \cdot \mathrm{CuSO}_{4}+4 \mathrm{SO}_{3}(\mathrm{~g})
$$

Within the temperature interval from $650{ }^{\circ} \mathrm{C}$ to $764{ }^{\circ} \mathrm{C}$, part of chalcocyanite is decomposed to tenorite, followed by an endothermal peak at $743{ }^{\circ} \mathrm{C}$ and mass decrease on TG curve [23]:

$$
\mathrm{CuSO}_{4} \rightarrow \mathrm{CuO}+\mathrm{SO}_{3}(\mathrm{~g})
$$

Above $700{ }^{\circ} \mathrm{C}$ magnetite is stable, so the part of hematite is transformed into magnetite:

$$
6 \mathrm{Fe}_{2} \mathrm{O}_{3} \rightarrow 4 \mathrm{Fe}_{3} \mathrm{O}_{4}+\mathrm{O}_{2}(\mathrm{~g})
$$

Temperature interval $764-850{ }^{\circ} \mathrm{C}$ was characterized by the occurrence of the endothermal peak on DTA curve at $796{ }^{\circ} \mathrm{C}$, with a mass decrease on TG curve, which corresponds to dolerophanite decomposition:

$\mathrm{CuO} \cdot \mathrm{CuSO}_{4} \rightarrow 2 \mathrm{CuO}+\mathrm{SO}_{3}(\mathrm{~g})$ 
Decomposition of gaseous $\mathrm{SO}_{3}$ can be described by Eq. 10 [23]:

$\mathrm{SO}_{3}(\mathrm{~g}) \rightarrow \mathrm{SO}_{2}(\mathrm{~g})+0,5 \mathrm{O}_{2}(\mathrm{~g})$

At higher temperatures $\left(890-945^{\circ} \mathrm{C}\right)$ magnetite transformed into maghemite (Eq. 11) [23]:

$4 \mathrm{Fe}_{3} \mathrm{O}_{4}+\mathrm{O}_{2}(\mathrm{~g}) \rightarrow 6 \gamma \mathrm{Fe}_{2} \mathrm{O}_{3}$

as well as tenorite further oxidation into cuprite:

$4 \mathrm{CuO}+4 \mathrm{SO}_{2}(\mathrm{~g})+\mathrm{O}_{2}(\mathrm{~g}) \rightarrow 2 \mathrm{Cu}_{2} \mathrm{O}+4 \mathrm{SO}_{3}(\mathrm{~g})$

Thermal treatment of the investigated copper concentrate showed that its oxidation during heating from $25{ }^{\circ} \mathrm{C}$ to $1000{ }^{\circ} \mathrm{C}$ involved several overlapping exothermal and endothermal reactions and the loss of volatile elements (arsenic and sulfur).

Kinetic analysis results

In solid-state reactions, appropriate kinetic equations, rate limiting steps, and calculation of kinetic parameters could supply a deeper conception into the possible transformation mechanisms [30]. Determination of the most probable reaction mechanism model(s) can be complicated for multi-step reaction kinetics [31]. The DTA and TG curves of non-isothermal decomposition of the investigated sulfide copper concentrate at four different heating rates $\left(5,10,15\right.$, and $\left.20^{\circ} \mathrm{C} \mathrm{min}{ }^{-1}\right)$ are shown in Fig. 5 and Fig. 6. According to previous results, following stages of the oxidation process were defined: I -moisture removal; II - oxidation of the surface layers of chalcopyrite; III - oxidation of the inner layers of chalcopyrite; IV - oxidation of enargite and tennantite; V - forming of dolerophanite; VI - decomposition of chalcocyanite into tenorite; VII - decomposition of dolerophanite into tenorite.

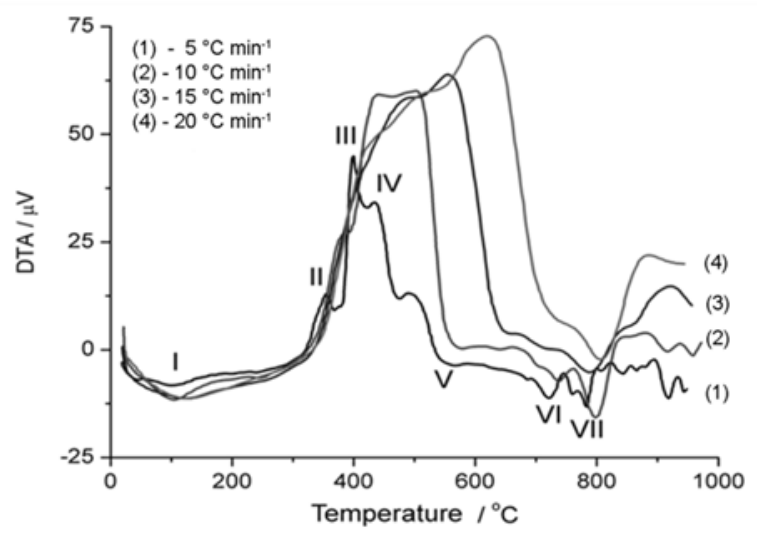

Fig. 5. DTA curves for thermal decomposition of sulfide copper concentrate at heating rates of $5,10,15$ and $20^{\circ} \mathrm{C} \mathrm{min}^{-1}$ in the air. 


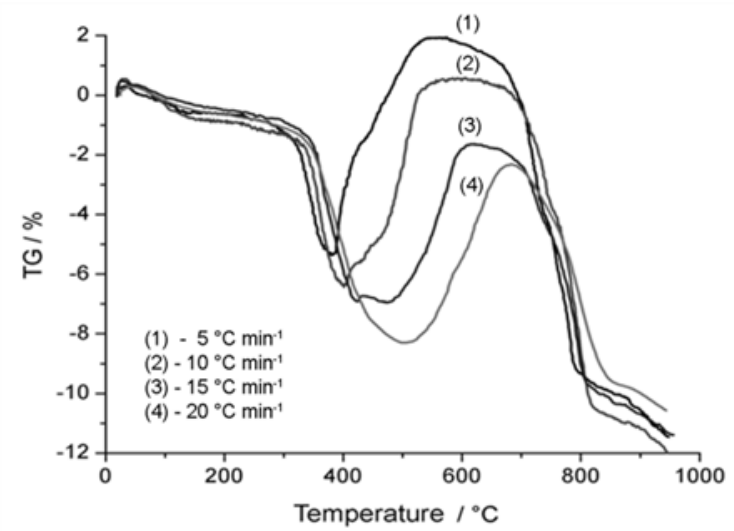

Fig. 6. TG curves for thermal decomposition of sulfide copper concentrate at heating rates of $5,10,15$ and $20^{\circ} \mathrm{C} \mathrm{min}^{-1}$ in the air.

Thermal analysis results were used to determine kinetic parameters (activation energy and pre-exponential factor) for the oxidation processes as described in the literature [32-36]. Kinetic analysis is based on the assumption that the rate constant $(\mathrm{k})$ is described by the Arrhenius equation:

$$
\mathrm{k}=\mathrm{A} \exp \left(-\frac{\mathrm{E}_{\mathrm{a}}}{\mathrm{RT}}\right)
$$

where $A$ is the pre-exponential factor, $E_{a}$ is the activation energy, $R$ is the universal gas constant, and $T$ is the absolute temperature. The DTA data $\left(\mathrm{T}_{\mathrm{m}}\right.$ - peak temperature) were processed and the kinetic parameters of the oxidation processes were obtained using the method of Ozawa [37, 38].

The peak temperatures $\left(\mathrm{T}_{\mathrm{m}}\right)$ from the DTA curves are shown $\mathrm{n}$ Table 3 .

Table 3. Peak temperatures from DTA curves.

\begin{tabular}{lccccccc}
\hline Heating rate & \multicolumn{7}{c}{ Peak temperature $\left(\mathrm{T}_{\mathrm{m}}\right) / \mathrm{K}$} \\
$(\Phi) / \mathrm{K} \mathrm{min}^{-1}$ & I & II & III & IV & V & VI & VII \\
\hline $\mathbf{5}$ & 373 & 631 & 676 & 708 & 840 & 995 & 1057 \\
$\mathbf{1 0}$ & 379 & 657 & 718 & 781 & 851 & 1005 & 1070 \\
$\mathbf{1 5}$ & 397 & 708 & 760 & 834 & 927 & 1012 & 1074 \\
$\mathbf{2 0}$ & 399 & 743 & 786 & 895 & 1005 & 1016 & 1079 \\
\hline
\end{tabular}

The Ozawa plot is shown In Fig. 7, as a relationship between $\ln (\Phi)$ and $10^{3} \mathrm{~T}_{\mathrm{m}}{ }^{-1}$, where $\Phi$ is the heating rate. 


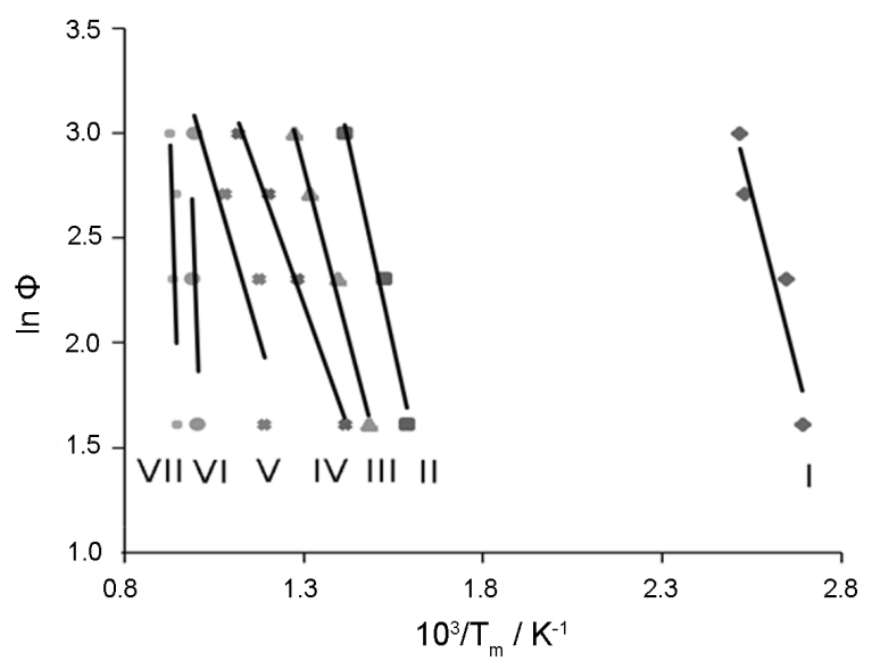

Fig. 7. The relationship between $\ln (\Phi)$ and $10^{3} \cdot T_{m}^{-1}$ (Ozawa plot).

The activation energy $E_{a}$ is calculated from the slope of the obtained straight line, and the pre-exponential factor $\ln \mathrm{A}$ is calculated from the intercept. All obtained data for activation energy $\left(E_{a}\right)$, the pre-exponential factor $(\ln A)$, and regression coefficient $\left(r^{2}\right)$ are presented in Table 4.

Table 4. Activation energies (Ea/kJ mol $\left.{ }^{-1}\right)$, pre-exponential factors $\left(\ln A / \mathrm{s}^{-1}\right)$, and regression coefficients $\left(r^{2}\right)$ obtained by Ozawa method for peak temperatures.

\begin{tabular}{lccccccc}
\hline $\begin{array}{l}\text { Kinetic } \\
\text { parameter }\end{array}$ & \multicolumn{7}{c}{ Peak No. } \\
& I & II & III & IV & V & VI & VII \\
\hline $\mathrm{Ea} / \mathrm{kJ} \mathrm{mol}^{-1}$ & 55 & 65 & 55 & 40 & 49 & 428 & 396 \\
$\ln \mathrm{A} / \mathrm{s}^{-1}$ & 19.68 & 14.05 & 11.37 & 8.38 & 9.0 & 53.63 & 47.02 \\
$\mathrm{r}^{2}$ & 0.91 & 0.97 & 0.99 & 0.99 & 0.96 & 0.91 & 0.95 \\
\hline
\end{tabular}

Calculated values for the activation energy show that all oxidation steps took place in the kinetic area. In stages defined by peaks I - III, activation energies were close to the values which correspond to transitional area, where both temperature and diffusion have impact on the reaction rate, while in stages defined by peaks VI and VII, the activation energy was rising sharply, indicating that temperature had the greatest impact on the reaction rate.

\section{Conclusions}

A sulfide copper concentrate from the domestic deposit (ore body "H", Serbia) was subjected to experimental investigation. Chemical analysis showed that the concentrate is the chalcopyrite-enargite-tennantite type, with arsenic content (3.44 mass $\%)$ high above the upper limit for metallurgical processing. The concentrate is also overburdened with gangue minerals. It can be concluded that this concentrate needs to 
be pretreated, or mixed with other conventional concentrates, in order to decrease the amount of arsenic, according to ecological demands and legislation.

Due to a better understanding of the structural, thermodynamic, thermal and kinetic behavior of the sulfide copper concentrate during oxidation in the air atmosphere, in the temperature range from 25 to $1000{ }^{\circ} \mathrm{C}$, simultaneous thermal (DTA/TG), XRD, and scanning electron-microscopic analyses (SEM/EDS) were performed. The obtained results indicated that oxidation process of the investigated sulfide copper concentrate occurred in three stages. The first stage can be described as binary sulfides decomposition followed by exothermal effects and mass decrease (below $600{ }^{\circ} \mathrm{C}$ ). Endothermal reactions of forming sulfates and oxysulphates in the second stage are followed by their decomposition into oxides above $850{ }^{\circ} \mathrm{C}$, with their further oxidation at temperatures close to $1000{ }^{\circ} \mathrm{C}$. Thermal treatment of the investigated copper concentrate showed that its oxidation during heating from $25{ }^{\circ} \mathrm{C}$ to $1000{ }^{\circ} \mathrm{C}$ involved several overlapping exothermal and endothermal reactions and the loss of volatile elements (arsenic and sulfur). According to these results, the reaction mechanism of the oxidation process was proposed. Kinetic analysis and calculations, performed by Ozawa method of non-isothermal kinetics, showed that all stages of the oxidation process took place in the kinetic area, indicating that the reactions were chemically controlled and the temperature had the greatest impact on the reaction rate.

\section{Acknowledgements}

Authors are grateful to the Ministry of Education, Science and Technological Development, the Republic Serbia, for the financial support (Projects TR 34023). Authors are also grateful to Mr. Milorad Ćirković from IRM Bor for helping in HSC Chemistry 6.1 calculations.

\section{References}

[1] G. Long, Y. Peng, D. Bradshaw: Miner Eng, 36-38 (2012) 179-186.

[2] K. Conner, C. Anderson: J Metall Eng, 2 (2013) 115-123.

[3] M. Schlesinger, M. King, K. Sole, W. Davenport, Extractive metallurgy of copper (5th ed.), Elsevier, Amsterdam, 2011.

[4] P.C. Chaubal, M. Nagamori: Metall Trans B, 19B (1988) 547-156.

[5] S.A. Degterov, A.D. Pelton: Metall Mater Trans B, 30(B) 1999 661- 669.

[6] V. Dutre, C. Vandecasteele: J Hazard Mater, 40 (1995) 55-68.

[7] N. Štrbac, D. Živković, Ž. Živković, I. Mihajlović, Sulfides-thermal, thermodynamic and kinetic analysis. Technical Faculty in Bor, Bor, 2005. (in Serbian)

[8] N. Štrbac, I. Mihajlović, D. Živković, Ž. Živković, B. Anđelić: J Univ Chem Technol Metall, 41 (2006) 161-166.

[9] B-S. Kim, E-Y. Kim, C-K. Kim, H-I Lee, J-S. Sohn: Mater Trans, 49 (2008) $1192-$ 1198.

[10]Baba, A. A., Ayinla, K. I., Adekola, F. A., Ghosh, M. K., Ayanda, O. S., Bale, R. B: Int J Min Eng Mineral Proc, 1 (2012) 1-16.

[11] Mitovski, N. Štrbac, I. Mihajlović, M. Sokić, J. Stojanović: J Therm Anal Calorim., 118 (2014) 1277-1285.

[12] V. Bazan, E. Brandaleze, L. Santini, P. Sarquis: Int J Nonferrous Metall, 2 (2013) 128-135.

[13]L. Winkel, I. Alxneit, M. Sturzenegger: Int J Min Proc, 88 (2008) 24-30. 
[14]M. Perez-Tello, H.Y. Sohn, J. Lottiger: Min Metall Proc, 16 (1999) 1-7.

[15]D. Živković, M. Sokić, Ž. Živković, D. Manasijević, Lj Balanović, N. Štrbac, V. Ćosović, B. Boyanov: J Therm Anal Calorim, 111 (2013) 1173-1176.

[16]R. Padilla, A. Aracena, M.C. Ruiz: Metall Mater Trans., 43B (2012) 1119-1126.

[17] S. Prasad, B. D. Panday: Can Metall Quart, 38 (1999) 237-247.

[18]L. Winkel, J. Wochele, C. Ludwig, I. Alxneit, M. Sturzenegger: Miner Eng, 21 (2008) 731-742.

[19] N. J. Welham: Hydrometallurgy, 62 (2001) 165-173.

[20] S. Perez-Fontes, M. Perez-Tello, L. Prieto, F. Brown, F. Castillon-Barraza: Miner Metall Proc, 24 (2007) 275-283.

[21] Antonijević, P. Mijatović: Annales Géologiques de la Péninsule Balkanique, 75 (2014) $59-74$

[22]C. Sahyoun, S.W. Kingman, N.A. Rowson: Phys Sep Sci Eng, 12 (2003) 23-30.

[23]L.E. Sargsyan, A.M. Hovhannisyan: Metall Min Ind, 2 (2010) 225-229.

[24]M. Sokić, I. Ilić, D. Živković, N. Vučković: Metallurgy, 47 (2008) 109-113.

[25]N. Štrbac, I. Mihajlović, D. Minić, D. Živković, Ž. Živković: J Min Metall, 45 (1) B (2009) 59-67.

[26] O. Kubaschewski, E.L. Evans, C.B. Alcock, Metallurgical Thermochemistry, Pergamon Press, Oxford, 1967.

[27] R.H. Hultgren, P.D. Desai, D.T. Hawkins, et al., ASM. Metals Park, Ohio, 1973, $39-46$.

[28] N. Chakraborti, D.C. Lynch: Metall Trans, 14 B (1983) 239-251.

[29] G. Harshe, S.Ventkatachalam: JOM, 36 (1986) 34-36.

[30] K.V. Tomashevitch, S.V. Kalinin, A.A. Vertegel, N.N. Oleinikov, V.A. Ketsko, Y.D. Tretyakov: Thermochim Acta, 323 (1998) 101-107.

[31] S.H. Shahcheraghi, G.R. Khayati, M. Ranjbar: J Therm Anal Calorim, 122 (2015) $175-188$.

[32] S. Vyazovkin, C. Wight: Annu Rev Phys Chem, 48 (1997) 125-149.

[33] S. Vyazovkin, C. Wight: Thermochim Acta, 5 (1999) 340-341.

[34] M.E. Brown, Introduction to the thermal analysis: techniques and applications (2nd ed.), Kluwer Academic Publishers, Dordrecht, 2001.

[35] S. Gyurov, D. Rabadjieva, D. Kovacheva, Y. Kostova: J Therm Anal Calorim, 116 (2014) 945-953.

[36] Mitovski, N. Štrbac, D. Manasijević, M. Sokić, A. Daković, D. Živković, Lj. Balanović: Metalurgija, 54 (2015) 311-314.

[37] T. Ozawa: J Therm Anal, 21 (1970) 301-324.

[38] T. Ozawa: Bull Chem Soc Jpn, 38 (1965) 1881-1886.

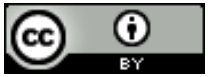

Creative Commons License

This work is licensed under a Creative Commons Attribution 4.0 International License. 